Ann. Biol. anim. Bioch. Biophys., I975, 15 (2), I47-I60.

\title{
LUTEAL REGRESSION IN DOMESTIC ANIMALS
}

\author{
W. HANSEL \\ Department of Animal Science, \\ New York State College of Agriculture, Cornell University, \\ Ithaca, N. Y., 14853 (U.S.A.)
}

\section{SUMMARY}

The ability of exogenous prostaglandin $\mathrm{F}_{2 x}\left(\mathrm{PGF}_{2 \alpha}\right)$ to cause corpus luteum regression in a number of species is well established; relatively low levels are required in ewe, cow, mare and sow and relatively high levels in man, Rhesus monkey, the bitch and rat. Evidence for a role of $\mathrm{PGF}_{2 x}$ in corpus luteum regression during the normal cycle in the ewe has been presented.

In experiments designed to shed light on the role of $\mathrm{PGF}_{2^{\alpha}}$ in luteolysis in the normal cow, samples of blood were collected from the ovarian artery, the uterine vein and the jugular vein. Samples of endometrial tissue were collected at the same time. PGF levels were elevated in the endometrial tissue and in uterine vein plasma at Days IO-I4, before jugular plasma progesterone declined. However, concentrations of PGF in ovarian arterial samples did not change during the cycle, and were not significantly higher than jugular plasma levels at any time. Relatively large amounts of arachidonic acid were present in the endometrium at Days IO-14. On the other hand clear evidence for a preferential transfer of $\mathrm{PGF}_{2 \alpha}$ to the ovarian artery was obtained in cattle given $6 \mathrm{mg} \mathrm{PGF}{ }_{2 \alpha}$ into the uterine lumen.

Significant elevations in plasma estrogen levels $4^{-I} 6 \mathrm{hrs}$ after $\mathrm{PGF}_{2 \alpha}$ injections were noted in several experiments. Arachidonic acid (3.0 mg) injected directly into the corpora lutea of locally anesthetized cows at the Ioth-I 2 th days of the estrous cycle was quickly converted to PGF and resulted in a very rapid increase in peripheral plasma estrone and estradiol concentrations. In an experiment carried out in ewes it was found that ovarian x-irradiation (I.500 rads), sufficient to cause destruction of the follicles and a grat reduction in plasma estrogen levels, prevented the luteolytic effects of exogenous $\mathrm{PGF}_{2 \alpha}$. These same doses of $\mathrm{PGF}_{2 \alpha}$ caused complete luteolysis and a return to estrus in sham-irradiated ewes, and in $\mathrm{x}$-irradiated ewes given estradiol benzoate in addition to the $\mathrm{PGF}_{2 \alpha}$.

Measurements of a specific, saturable, high affinity estrogen binding protein in bovine luteal tissues collected throughout the estrous cycle revealed that levels were low, or unmeasurable

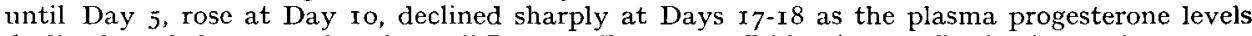
declined, and then rose sharply until Day 2o. Exogenous $\mathrm{PGF}_{2} \alpha$ is not effective in causing corpus luteum regression in the cow when administered prior to Day 5 .

Collectively, these results suggest that estrogens may be involved in both naturally occurring and $\mathrm{PGF}_{2}$-induced regression of the corpus luteum.

\section{INTRODUC'TION}

Evidence summarized in a recent review (HANSEL, et al., I973) clearly associates corpus luteum maintenance with absence of the glandular epithelial elements of the endometrium. The uterine luteolytic effects in the ewe and cow appear to be local 
and depend on the presence of the uterine horn ipsilateral to the corpus luteum (HANSEI et al., I973). These observations and many others suggest that the uterus produces one or more substances capable of acting locally to cause corpus luteum regression and a decline in progesterone secretion in the ewe and cow.

GodiNG (I974) has argued that prostaglandin $\mathrm{F}_{2 \alpha}\left(\mathrm{PGF}_{2 \alpha}\right)$ is the uterine luteolysin in the ewe. There is no doubt that exogenous $\mathrm{PGF}_{2 \alpha}$ is luteolytic in the ewe, as it is in many other species, and there is considerable evidence for a perferential transfer of PGF infused into the uterine ovarian vein to the closely adherent ovarian artery (GoDING, I974). Several studies have established that infusion of $20-25 \mu \mathrm{g}$ of $\mathrm{PGF}_{2} \alpha$ /hour for $4-8$ hours into the uteine vein ipsilateral to the corpus luteum is sufficient to cause luteolysis in the ewe (HANSEL et al., I973). Goding (I974) argues, partly on the basis of the data of THORBuRN et al. (I972), that peak levels of PGF measured in the uterine veins of normal ewes are sufficiently high to produce luteo1ysis. However, it must be pointed out that the peak levels (up to $22 \mathrm{ng} / \mathrm{ml}$ ) measured by THORBURN et al. (I972) represent levels in utero-ovarian vein blood, and the possibility that the ovary may contribute a considerable part of the PGF measured in utero-ovarian vein blood must be considered. BAIRD et al. (I973) reported much lower values for ovine uterine vein blood $(0.47 \mathrm{ng} / \mathrm{ml}$ on Days 9 , Io or II and $\mathrm{I} .38 \mathrm{ng} / \mathrm{ml}$ on Days I4, I5 or I6). Frequent measurements of $\mathrm{PGF}_{2} \alpha$ in ovarian arterial blood during the estrous cycle of the ewe have not been reported.

Exogenous $\mathrm{PGF}_{2}$ is also luteolytic in the cow. HANSEL and SCHECH'TER (I972) reported that infusion of $\mathrm{PGF}_{2}$ for 6 hours at a rate of $5^{\circ} \mu \mathrm{g} /$ hours directly into the ovarian artery resulted in a rapid decline in jugular plasma progesterone from $3.0 \mathrm{ng} / \mathrm{ml}$ to less than I $\mathrm{ng} / \mathrm{ml}$ within 20 hours. Rowson et al. (I972) reported successful synchronization of estrous cycles following intrauterine injections of $0.5 \mathrm{mg} \mathrm{PGF}_{2}$ on two successive days, while HANSEL and SCHECHTER (I972) reported synchronization after single injections of $5 \mathrm{mg}$ of $\mathrm{PGF}_{2 \alpha}$ into the uterus. Animals treated during the first four days of the cycle have failed to respond in all experiments reported to date. Subsequent studies (HAFs et al., r974, for example) established that intramuscular injections of $30 \mathrm{mg} \mathrm{PGF}{ }_{2}$ are effective. Conception rates equal to those obtained in control animals have been obtained in cattle inseminated following $\mathrm{PGF}_{2 x}$ treatments, provided treatments were given later than the 4 th day of the cycle.

However, relatively little evidence has been reported to establish a role for $\mathrm{PGF}_{2 \alpha}$ in luteolysis in the normal cow. HANSEL et al. (I973) reported isolation from bovine endometrial tissue of a highly unsaturated fatty acid capable of causing luteolysis in pseudopregnant hysterectomized hamsters. This fatty acid was subsequently identified as arachidonic, the immediate precursor of PGF $_{2 \alpha}$ (SHFMESH et al., I974). Scotr et al. (I968) had previously reported that arachidonic acid constitutes more than half of the relatively large amounts of polyunsaturated fatty acids present in the bovine corpus luteum at Days 9-I5 of the estrous cycle.

SHEMESH and HANSEL (I975 a) measured PGF in ovarian arterial, uterine venous and jugular plasmas and in endometrial tissues at various times during the bovine estrous cycle, and related these values to concurrently determined peripheral plasma progesterone levels. Four groups of heifers at Days I-5, I0-I4, I5-I7 and 20-0 of the estrous cycle were studied. Low levels of PGF (48 $\pm \mathrm{I} 2 \mathrm{ng} / \mathrm{g}$ dry tissue) were measured in the endometrium on Days I-I 4 of the cycle. Higher values ( $13 \mathrm{I} \pm 9.0 \mathrm{ng} / \mathrm{g}$ dry tissue) were found at Days I5 until the day of estrus $(p<0.001)$. Similarly, 
very low levels of PGF were observed in the uterine vein plasma at Days I-I4 (0.I62 $\pm 0.044 \mathrm{ng} / \mathrm{ml}$ ), whereas on Days I5 until the day of estrus the levels ranged from 1.5 to $3.0 \mathrm{ng} / \mathrm{ml}$. The increases in uterine vein PGF on Day $I_{5}$ occurred even while peripheral plasma progesterone levels were still high. However, PGF was not elevated in either the ovarian artery or the jugular vein at any time during the cycle, even when uterine vein levels were greatly elevated. No differences in PGF content were detected in endometrial tissue from uterine horns adjacent or opposite to the functional corpus luteum.

Although these data fail to lend support to the idea that preferential transfer of $\mathrm{PGF}_{2 \alpha}$ from the uterine vein to the ovarian artery plays a role in luteolysis in untreated cattle, it seems clear that $\mathrm{PGF}_{2 \alpha}$ is preferentially transferred to the ovarian artery after relatively large amounts are placed in the uterine lumen. Hixox and HANSEL (I974) cannulated a small branch of the ovarian artery in the hilus of the ovary in five normal cows, and $6 \mathrm{mg}$ of $\mathrm{PGF}_{2}$ was injected into the lumen of the uterine horn ipsilateral to the cannula on Day I I or I 2 of the cycle. Frequent samples were collected simultaneously from the ovarian artery, carotid artery and jugular vein. The concentration of prostaglandins of the $F$ series (PGF) was observed to increase rapidly at all three sampling sites following administration of $\mathrm{PGF}_{2 x}$. While the concentration was highest in the carotid and jugular within five minutes of treatment, the concentration of PGF continued to increase in the ovarian artery to reach a peak $40 \mathrm{~min}$ after treatment and remained at levels significantly greater $(p<0.05)$ than jugular or carotid levels for $80 \mathrm{~min}$. Intrauterine administration of $6 \mathrm{mg}$ of $\mathrm{PGF}_{2}$ was luteolytic, as judged by a fall in plasma progesterone concentrations and a mean corpus luteum weight of $\mathrm{r} .83 \pm 0.22 \mathrm{gm}$ upon termination of the experiment 72 hours after treatment. Peripheral plasma estrone and estradiol- 7 B levels were observed to increase to a peak 9 hours after treatment, after which a slight increase in the mean plasma $\mathrm{LH}$ concentration occurred.

In view of these results, it was decided to carry out further experiments to determine the mechanism(s) by which $\mathrm{PGF}_{2} \alpha$ induces luteolysis in ruminant animals.

\section{MATERIAI, AND ME'THODS}

Unless otherwise stated, all cattle used in the experiments described were mature Holstein heifers or cows weighing between 365 and $550 \mathrm{~kg}$. All animals had at least one normal estrous cycle prior to treatment and were treated at known days of the cycle (estrus = Day o). Treatments are described in detail for each experiment. The ewes used were Western Whiteface animals treated at known stages of normal estrous cycles.

\section{Surgical procedures}

Corpora lutea were removed through an incision in the anterior vagina (HANSEL, I97I). Cannulations of ovarian arteries and veins were made in standing animals under local anesthesia consisting of paralumbar blocks and local infiltrations of procaine hydrochloride. Hysterectomies and collections of uterine venous and ovarian arterial blood samples were carried out under general anesthesia maintained with halothane. Ewes were anesthetized with halothane and the exposed ovaries were surrounded by a lead shield and subjected to $\mathrm{x}$-irradiation or sham irradiation. 
Plasma LH determinations were made by the solid phase radioimmunoassay described by HoBson and HANSEL (1972). The estrogen cytosol binding protein was measured by techniques described by Kimball and Hansel (I974). Progesterone was determined by radioimmunoassays, as described by Hixon et al. (1973) or by radioligand techniques, as described by EchterNKAMP and HANSEL (I973). Estrone $\left(E_{1}\right)$ and estradiol $\left(E_{2}\right)$ were determined by radioimmunoassays, as described by Echternkamp and Hansel (r973) and Hixon and Hansei (1974). Prostaglandins of the F-series were determined as described by Hrxon et al. (1973) and SHEMESH and HANSEL (1975 b).

\section{RESULTS}

\section{Effects of $P G F_{2 \alpha}$ and arachidonic acid administered directly into the bovine ovary}

Two experiments have been carried out to study local effects of PGF and its precursor, arachidonic acid on ovarian function. In the first experiment (HIxON et al., I973), $\mathrm{PGF}_{2 \alpha}(300 \mu \mathrm{g})$ was injected directly into the ovaries of five heifers at the I2-I4th days of the cycle through a long hypodermic needle inserted into the body cavity through the skin between the anus and the tuber ischii. The tip of the needle was directed into the corpus luteum, which was held by a hand inserted into the rectum. Although an attempt was made to inject the $\mathrm{PGF}_{2 \alpha}$ directly into the corpus luteum it cannot be stated with certainty that all of the $\mathrm{PGF}_{2 \alpha}$ was placed into the corpus luteum of each animal. Four heifers treated in an identical fashion with $0.25 \mathrm{ml}$ of the Tham buffer used as a vehicle for the $\mathrm{PGF}_{2 \alpha}$ served as controls. Jugular blood samples collected at frequent intervals during the ensuing $7^{2}$ hours were analyzed for progesterone, $\mathrm{E}_{1}, \mathrm{E}_{2}$ and $\mathrm{PGF}$, and the results are shown in figure $\mathrm{I}$.

The interesting point to be made about these data is that plasma estrogen levels rose significantly $(p<0.05)$ between 4 and 16 hours in PGF P $_{2}$ treated animals, when compared to vehicle injected control animals, even though plasma progesterone levels remained relatively high. The levels of $\mathrm{PGF}_{2}$ injected into the ovary caused a decrease in plasma progesterone levels $(p<0.05)$ but concentrations remained above $3.0 \mathrm{ng} / \mathrm{ml}$ during most of the experiment. Jugular plasma PGF levels were transiently elevated but had returned to control levels by 4 hours. A small rise in plasma PGF concentration occured in the control animals at the same time, perhaps as a result of manipulation of the ovary.

Since arachidonic acid was found in large amounts in the bovine endometrium (SHEMEsh et al., I974) and proved to be luteolytic in the pseudopregnant hamster, and rabbit (HoFFMAN, I974), it seemed appropriate to study the effects of this fatty acid on corpus luteum function in the cow (SHEMESH and HANSEL, I975 $b$ ).

Eight normal Holstein hiefers at the I2th or I3th day of the estrous cycle were used in this study. A total of $3 \mathrm{mg}$ of arachidonic acid in I $\mathrm{ml}$ of a $0 . \mathrm{I} \mathrm{M}$ Tham [Tris(hydroxy-methyl)aminoethane] buffer at $\mathrm{pH} 7.0$ was administered to four animals; four others treated in an identical fashion with the buffer served as controls. Flank laparotomies were made in all animals under local anesthesia, and the uterine branch of the utero-ovarian vein was cannulated so that frequent ovarian venous samples could be collected. At the same time, a catheter was placed 


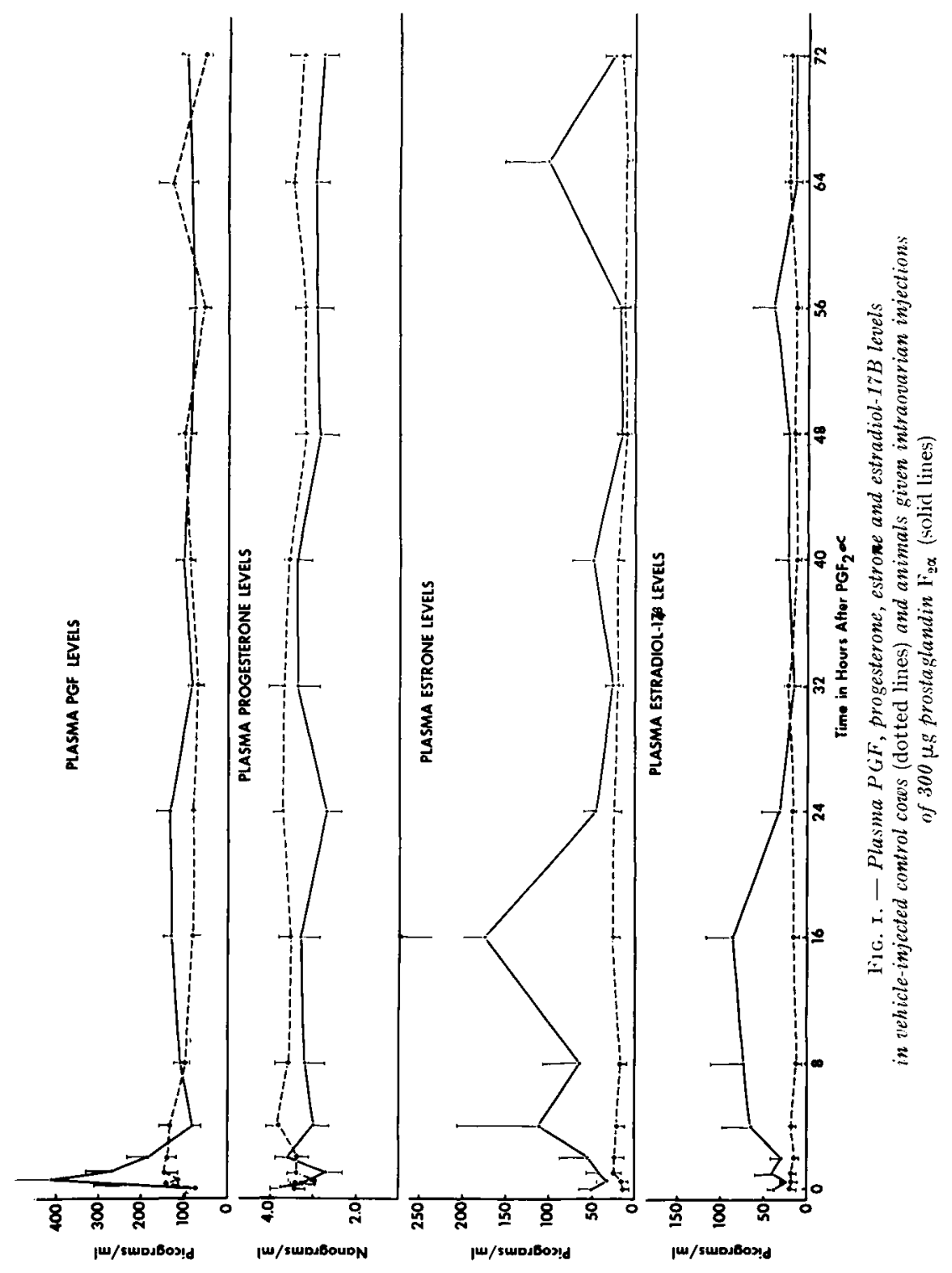


into the jugular vein, and frequent blood collections from both veins were made during a 75 hour period. The arachidonic acid ( $1.5 \mathrm{mg}$ ) was injected directly into the luteal tissue at $o$ and again at 4.5 hours (fig. 2). Blood was immediately centrifuged at $4^{\circ} \mathrm{C}$ and plasma was frozen in aliquots for prostaglandin, progesterone, luteinizing hormone and estrogen determinations. At 72 hours the corpora lutea were removed through an incision in the anterior wall of the vagina.
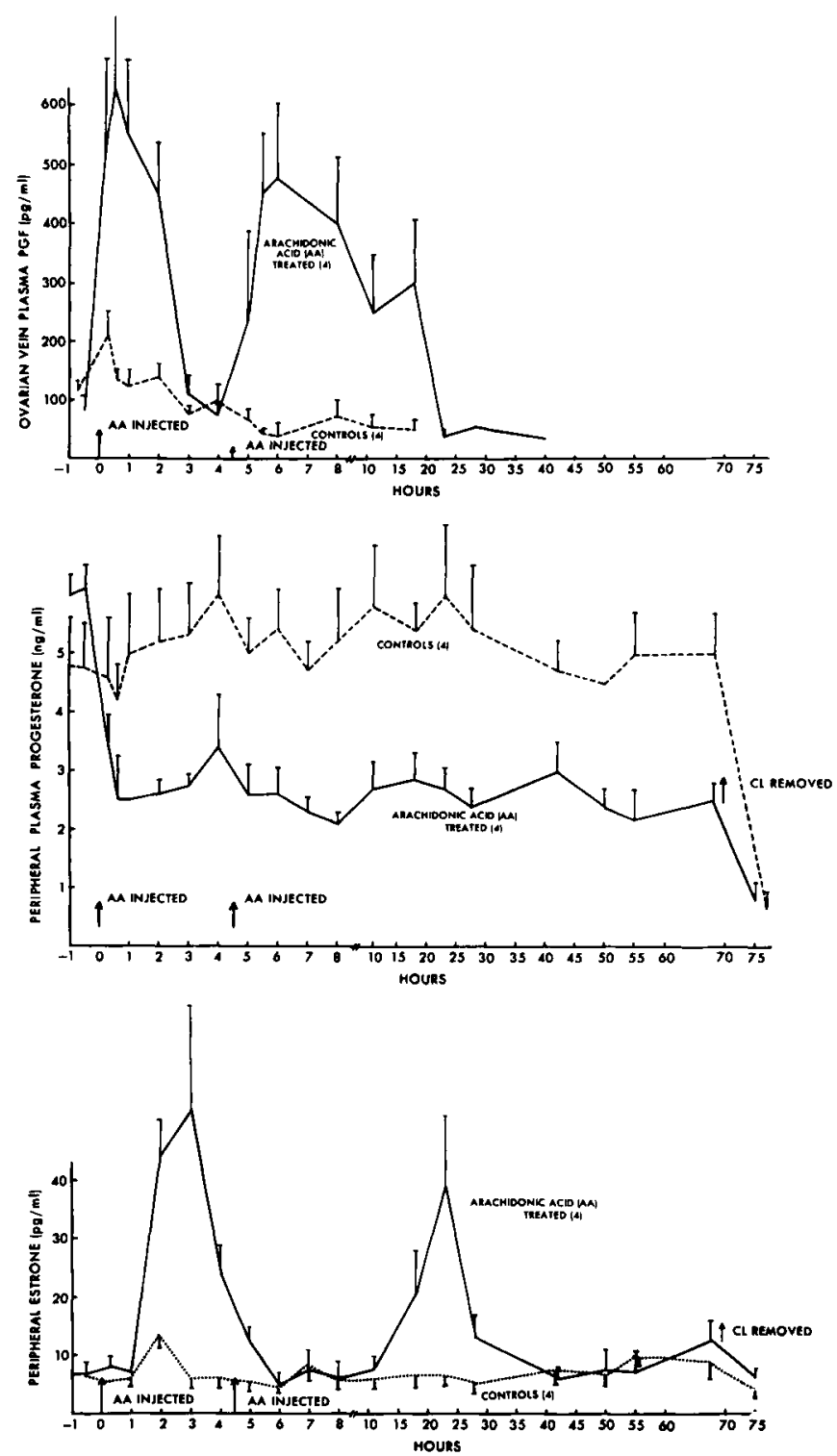

FIG. 2. - Concurrent changes in jugular plasma levels of progesterone and estrone and in ovarian venous plasma levels of prostaglandin $F$ before and after injections of arachidonic acid ( $1.5 \mathrm{mg}$ at $\mathrm{I} .0$ and 4.5 hours) and vehicle buffer into normal Holstein heifers at the 12th or 13th day of the estrous cycle. Vertical bars represent standard errors of the mean. ( ) : number of animals 
The results of this experiment are shown in figure 2, from which it may be seen that PGF levels in ovarian venous blood rose to extremely high levels immediately following. each injection of arachidonic acid into the corpora lutea. Peripheral plasma progesterone levels declined significantly $(p<0.05)$ from $6.0 \mathrm{ng} / \mathrm{ml}$ to an average of $2.5 \mathrm{ng} / \mathrm{ml}$, but did not decline further until the corpus luteum was removed at 72 hours. Large peripheral plasma estrone peaks were associated with each PGF peak in each treated animal. In contrast, neither PGF levels in ovarian venous blood, nor estrone nor progesterone levels in peripheral blood changed appreciably in the control cows. PGF levels were significantly higher in the ovarian vein samples from treated animals than in the controls at 0.5 hour $(p<0.005)$ and at 6 hours $(p<0.005)$. Estrone levels were significantly elevated in the treated animals at 3 hours $(p<0.05)$ and 16 hours $(p<0.05)$. It should be noted that a small rise in ovarian venous $\mathrm{PGF}$ and a concurrent small rise in jugular venous estrone occurred immediately after the first injection of the buffer in the control animals. This small peak in $\mathrm{PGF}$ possibly represents a release in response to manipulating the tissue. The levels of estradiol-I $7 \mathrm{~B}$ in jugular vein plasma paralleled the estrone levels in all cases, and were slightly lower.

These results indicate that the bovine ovary has the ability to convert arachidonic acid to PGF, and they further suggest that the large amounts of PGF produced in this way stimulated estrogen secretion, and eventually caused significantly $(p<0.05)$ decreased progesterone levels. However, complete luteal regression did not occur, as indicated by the further decline in plasma progesterone noted after removal of the corpus luteum at 72 hours. The corpora lutea removed at 72 hours from the arachidonic acid treated animals weighed $4.3 \pm \mathrm{I} .4$ grams, as compared to $6.3 \pm 0.5$ grams for the corpora lutea of the control animals $(p<0.10)$.

\section{$P G F_{2}$ and $E_{2}$ in ewes after x-irradiation of the ovaries}

In view of these results in cattle, it was hypothesized that estradiol may be required for the luteolytic action of $\mathrm{PGF}_{2} \alpha$. The hypothesis was tested in ewes whose ovarian follicles were destroyed by $\mathrm{x}$-irradiation to remove the primary source of estrogens (HrxoN et al., I974). The luteolytic effects of PGF $2 \alpha$, estradiol benzoate $\left(\mathrm{E}_{2} \mathrm{~B}\right)$ and $\mathrm{PGF}_{2} \alpha+\mathrm{E}_{2} \mathrm{~B}$ were compared in sham and $\mathrm{x}$-irradiated ewes. If this hypothesis were correct, luteolysis should not be observed following $\mathrm{PGF}_{2} \alpha$ treatment in $x$-irradiated animals, but should occur following replacement therapy with $\mathrm{E}_{\mathrm{a}} \mathrm{B}$.

Eight groups of animals with five ewes per group were employed in this study. The ovaries of animals in four of the groups were exteriorized through an midventral incision on Day 7 of the cycle and subjected to $x$-irradiation ( 1.500 rads). The ovaries of animals in the remaining four groups were sham-irradiated by exteriorization of the ovaries for the length of time required for $x$-irradiation. A group of sham-irradiated ewes and a group of $x$-irradiated ewes each received one of the following treatments : I) control injections of the vehicte for $\mathrm{PGF}_{2 \alpha}$ (Tham buffer, $\mathrm{pH} 8.0)$ t the vehicle for $\mathrm{E}_{2} \mathrm{~B}$ (sesame oil) ; $\mathrm{PGF}_{2 \alpha}(7 \mathrm{mg})+$ sesame oil ; 3) Tham buffer $+\mathrm{E}_{2} \mathrm{~B}(740 \mu \mathrm{g})$; and 4) $\mathrm{PGF}_{2} \alpha+\mathrm{E}_{2} \mathrm{~B}$. Each treatment was administered by intramuscular injection at 72 and again at 96 hours after sham and $x$-irradiation. Jugular blood samples were collected before treatment, at $0.25,0.50,1,2,3$ and 6 hours

Annales de Biologie animale. - 1975 . 
after each treatment and at 6 hours intervals thereafter for 96 hours after the first treatment. Plasma from these samples was analyzed for progesterone, estradiol- $7 \mathrm{~B}$ and $\mathrm{LH}$.
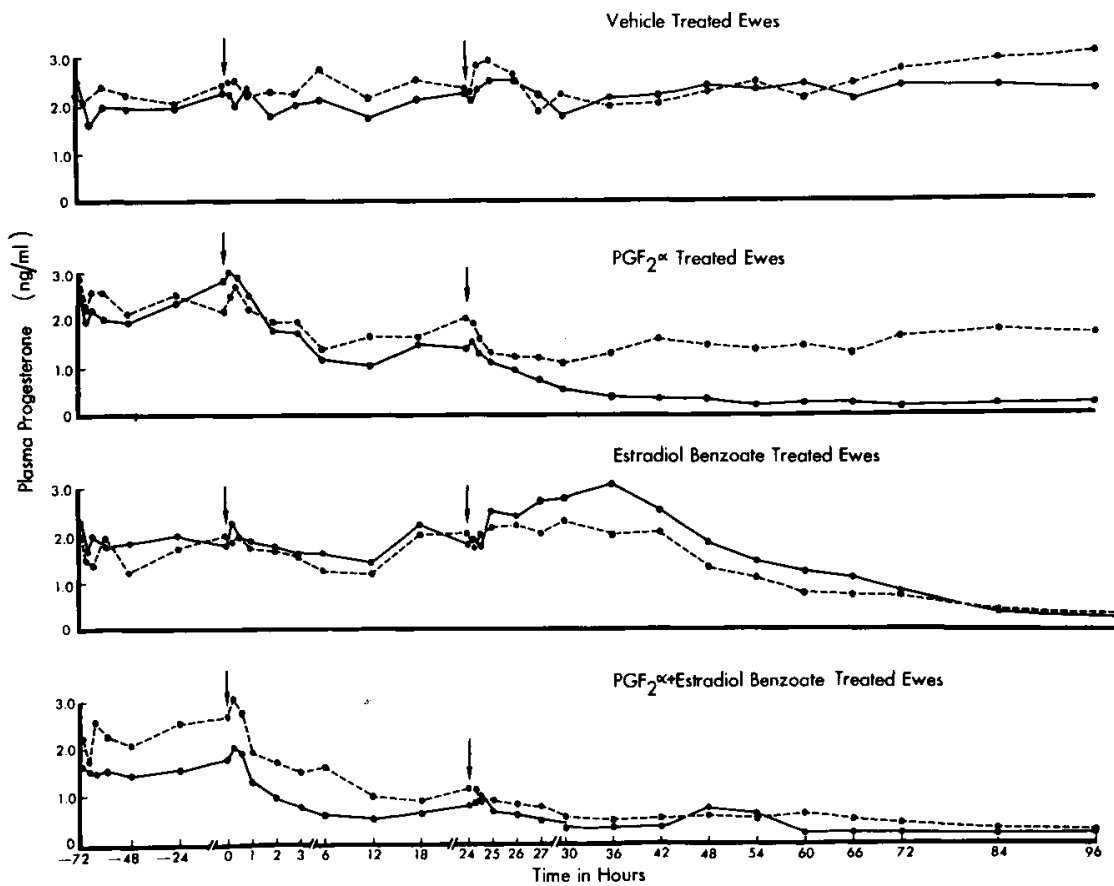

FIG. 3. - Plasma progesterone levels in ovarian $x$-irradiated (dotted-lines) and sham-irradiated (solid lines) ewes before and after treatments with $P G F_{3}$ and $E_{2} B$ alone and in combination (S. E. M. = o.23)

As may be seen in figure 3, plasma progesterone levels in both $\mathrm{x}$-irradiated and sham-irradiated animals treated with control injections of the rehicle remained between 2.0 and $3.0 \mathrm{ng} / \mathrm{ml}$ during the entire experiment. The progesterone values did not differ significantly $(p<0.05)$ suggesting that $x$-irradiation did not impair luteal function. However, the mean progesterone concentrations were significantly lower $(p<0.05$ ) from 36 through 96 hours (fig. 3) in sham-irradiated ewes treated with $\mathrm{PGF}_{2 x}$ than in the $\mathrm{x}$-irradiated animals treated with $\mathrm{PGF}_{2 x}$. Complete luteolysis occurred in sham-irradiated ewes and all of them returned to estrus within 96 hours. In contrast, luteolysis occurred in only one of the $\mathrm{x}$-irradiated, $\mathrm{PGF}_{2 x}$ treated animals and this animal had a luteinized cystic follicle at autopsy. Plasma estradiol levels as high as II.6 pg/ml were detected in this animal, while plasma estradiol levels in the remaining $\mathrm{x}$-irradiated animals (vehicle-treated and $\mathrm{PGF}_{2} \alpha^{-}$ treated) were below the sensitivity of the assay $(2.0-3.0 \mathrm{pg} / \mathrm{ml})$. The mean estradiol concentration in $\mathrm{PGF}_{2} \alpha$-treated, sham irradiated ewes increased from 7.4 to $8.3 \mathrm{pg} / \mathrm{ml}$ and from 3.9 to $8.9 \mathrm{pg} / \mathrm{ml}_{5} \Upsilon_{5}$ min after the first and second injections of $\mathrm{PGF}_{2 x}$, respectively (fig. 4). These results suggest that destruction of ovarian follicles to remove the primary source of estradiol inhibited the luteolytic action of $\mathrm{PGF}_{2}$. 



IiG. 4. - Plasma estradiol-1 $\mathrm{B}$ B levels in ovarian $x$-irradiated (dotted-lines) and sham-irradiated (solid lines) ewes before

and after treatments with $P G F_{2 \alpha}$ and $E_{2} B$ alone and in combination

Treatment of both sham and $\mathrm{x}$-irradiated animals with $\mathrm{E}_{2} \mathrm{~B}$ was luteolytic, as judged by mean luteal weights and plasma progesterone concentrations (fig. 3 ). However, progesterone levels were not significantly depressed until 54 to 60 hours after the first injections. Treatment of both sham and $x$-irradiated animals with $\mathrm{E}_{2} \mathrm{~B}$ and $\mathrm{PGF}_{2 x}$ was also luteolytic. Plasma progesterone levels were significantly reduced $(p<0.05)$ below control levels from I hour after the Ist injection through 96 hours in sham-irradiated animals and from 12 hours through 96 hours in the $x$-irradiated group. The combined treatment therefore produced significant differences much earlier than were observed after other treatments, suggesting an interaction between $\mathrm{PGF}_{2}$ and $\mathrm{F}_{22} \mathrm{~B}$ to cause luteolysis. The fact that effects were noted earlier in the $\mathrm{x}$-irradiated $\mathrm{PGF}_{2}$ and $\mathrm{F}_{2} \mathrm{~B}$ group than in the $\mathrm{x}$-irradiated $\mathrm{E}_{2} \mathrm{~B}$ treated group also suggests that replacement therapy with $\mathrm{E}_{2} \mathrm{~B}$ allowed expression of the luteolytic actions of $\mathrm{PGF}_{2} \alpha$.

In summary, treatment with $\mathrm{PGF}_{2}$ did not result in luteolysis in $\mathrm{x}$-irradiated animals where estradiol levels were below the limit of sensitivity of the assay; 


replacement therapy with $\mathrm{E}_{12} \mathrm{~B}$ allowed luteolysis to occur. A more rapid decrease in plasma progesterone concentration followed treatment with $\mathrm{PGF}_{2} \alpha+\mathrm{E}_{2} \mathrm{~B}$ than after either treatment alone. Therefore, estradiol was required for the luteolytic action of $\mathrm{PGF}_{2 \alpha}$ in this experiment.

\section{Levels of a specific estrogen binding protein in the bovine corpus luteum during the estrous cycle}

If estrogens play a role in corpus luteum regression in normal animals, one might expect to find a specific, saturable estrogen binding protein with high affinity in the tissue. KIMBALL and HANSEL (I974) systematically examined corpora lutea and endometrial tissues collected from cows at all stages of the estrous cycle for a specific cytosol binding protein and measured plasma levels of progesterone, $\mathrm{E}_{1}, \mathrm{E}_{2}$ and $\mathrm{LH}$ in the same animals. An estrogen specific binding protein saturable within the physiological range $\left(\mathrm{IO}^{-9} \mathrm{M}\right)$ was found in the corpus luteum; it was first measurable at Day 5, increased significantly from Day 5 to Day Io $(p<0$. or $)$ and remained at this level through Days $\mathbf{I}_{3}-\mathbf{I}_{5}$ (fig. 5). There was a significant $(p<0.01)$ decline in binding protein concentration at Days $17-18$, at the same time as the plasma progesterone concentrations declined. There was an increase in concentration of luteal binding protein at Day $2 \mathrm{I}$ to a level higher than at any other time during the cycle. The fact that the decline in estrogen-binding capacity occurs when the corpus luteum is transitional between normal secretory activity and functional regression suggests that these changes may be related to luteal regression at the end of a normal cycle. It is also worth pointing out that the appearance of the binding protein at Day 5 correlates well with the time during the cycle at which the borine corpus luteum first becomes responsive to exogenous $\mathrm{PGF}_{2}$.

\section{DISCUSSION}

Collectively, these and other results strongly suggest that estrogens are involved in both naturally occurring and $\mathrm{PGF}_{2 \alpha}$-induced regression of the corpus luteum in the cow and ewe. The rapid increases noted in $\mathrm{PGF}_{2} \alpha$ and estrogen secretion after injections of arachidonic acid in vivo into the bovine corpus luteum suggest that estrogen synthesis by the luteal itself may have been stimulated by $\mathrm{PGF}_{2 x}$. $\mathrm{PGF}_{2 \alpha}$ is known to stimulate progesterone production by bovine luteal tissue in vitro (see HANSEL ot al., I973), and also appears to have a transient stimulatory effect on progesterone secretion in vivo (see fig. 3, for exemple). Although the bovine corpus luteum is thought to be incapable of carrying steroidogenesis beyond progesterone and its metabolites (see SAVARD, I973), recent studies in our laboratory (SHEMESH and HANSEL, unpublished data) suggest that addition of either $\mathrm{PGF}_{2 \alpha}$ or arachidonic acid to bovine luteal tissue collected at Days $\mathrm{r} 2-\mathrm{r} 7$ of the cycle results in testosterone synthesis.

On the other hand, the fact that follicle destruction in the ewe prevented the luteolytic action of $\mathrm{PGF}_{2}$ and resulted in peripheral plasma estradiol levels at or below the limit of sensitivity of the radioimmunoassay suggests that estrogens of follicular origin are of major importance to luteolysis in this species. It should 
also be pointed out that the increase in peripheral plasma estrogens in the ewe following $\mathrm{PGF}_{2} \alpha$ treatment was very small when compared to that which occurred in the cow (see fig. I and 3). Real differences may exist between the two species in this respect, and the whole question of steroidogenesis beyong progesterone in luteal tissues needs to be reexamined.

We do not interpret these results to mean that estrogens constitute the final luteolytic agent, and that the only role of $\mathrm{PGF}_{2} \alpha$ is to increase estrogen secretion. If such were the case, exogenous estrogens should be much more effective than they are in inducing luteolysis in both the hysterectomized cow (BRUNNER ot al., Ig69) and ewe (STORMSHAK et al., I969). Furthermore, the corpora lutea of ovarian $\mathrm{x}$-irradiated ewes, although maintained through Day $\mathrm{I} 7$ of the cycle, usually degenerate by about Day 20 (Roche et al., I974). In addition, it should be pointed out that we have tested only one level of $\mathrm{PFG}_{2}$ in ovarian $\mathrm{x}$-irradiated ewes, and it is possible that a very high level of $\mathrm{PGF}_{2 \alpha}$ might induce "luteolysis " in $\mathrm{x}$-irradiated ewes by virtue of its ability to cause a prolonged reduction in blood flow through the corpus luteum.

Rather, we suggest as a working hypothesis, that luteolysis in these species is an active process, involving increased steroidogenesis and requiring an interaction among estrogen, $\mathrm{PGF}_{2}$ and a specific estrogen binding protein. It has previously been shown (HANSEL it al., I973) that treatment of normal cattle with small doses of $\mathrm{E}_{2} \mathrm{~B}$ on Days IO-I2 inclusive completely abolishes the ability of their luteal tissue to respond to $\mathrm{LH}$ in vitro.

$$
\text { Colloque : Control of sexual cycles in domestic animals }
$$
October 27-30, 1974, Nousilly.

\title{
ACKNOWLEDGMEN'TS
}

The experiments described were carried out by a team of workers consisting of the author, D. Gexgexbach, J. E. Hixox, M. Shemesh and R. Saatmax. The technical assistance of Denise Lensing and Cathy Mazauskas is gratefully acknowledged. The funds for the experiments describel were provided by NIH Grants HD-067I 8 and NIH 69-2209 and the Cooperative Regional Research Project NE-72, entitled Control of Reproduction in the Bovine Female.

\author{
RÉSUMÉ \\ RÉGRESSION DU CORPS JAUNE CHEZ IES ANIMAUX DOMLSTIQULS
}

Il a été bien établi que la prostaglandine $\left(\mathrm{PGF}_{2 \alpha}\right)$ exogène est capable de provoquer la régression du corps jaunc chez un certain nombre d'espèces. Des doses relativement basses sont nécessaires chez la Brebis, la Vache, la Jument et la Truic alors qu'il faut des doses relativement élevées chez l'Homme, le Singe (Rhésus), la Chienne et le Rat. Il a été présenté également des arguments en faveur d'un rôle joué par $\mathbf{P G I}_{2 x}$ dans la régression du corps jaunc pendant le cycle normal do la Brebis.

Dans des expériences conçues pour expliquer le rôle de $\mathrm{PGF}_{2 \alpha}$ dans la lutéolyse chez la Vacho normale, des échantillons de sang ont été recueillis dans l'artère ovarienne, la veine utérine, et la veine jugulaire. Des échantillons d'endomètre ont été prélevés en même temps. 11 a été constaté que les concentrations de PGF sont élevées dans l'endomètre, et dans le plasma de la veine 
utérine entre le jour io et I 4 du cycle, avant que les concentrations de progestérone dans la veine jugulaire ne diminuent. Cependant, les concentrations de PGF dans les échantillons de l'artère ovarienne n'ont pas changé durant le cycle, et n'ont été à aucun moment, significativement plus élevées que celles de la veine jugulaire. Des quantités relativement élevées d'acide arachidonique ont été trouvées dans l'endomètre entre les $\mathbf{I}^{\mathbf{e}}$ et $\mathbf{1}_{4}{ }^{\mathbf{e}}$ jours. D'autre part, une preuve très nette pour un transfert préférentiel de $\mathrm{PGF}_{2 \alpha}$ dans l'artère ovarienne a été obtenue chez des Vaches recevant $6 \mathrm{mg}$ de $\mathrm{PGF}_{2}$ dans la lumière utérine. Des augmentations significatives des concentrations d'œestrogènes dans le plasma, 4 à $I 6$ heures après les injections de PGF PG $_{2}$ ont été observées dans plusieurs expériences. L'acide arachidonique $(3,0 \mathrm{mg})$ injecté directement dans le corps jaune de Vaches sous anesthésie locale, entre le Io $^{\mathrm{e}}$ et le $\mathbf{I} 2^{\mathrm{e}}$ jour du cycle a été rapidement transformé en PGF ; il en est résulté une augmentation très rapide des concentrations d'œestrone et l'œstradiol dans le plasma.

Dans une expérience conduite chez des Brebis il a été trouvé que l'irradiation aux ravons $\mathrm{X}$ de l'ovaire (I 50o Rads), suffisante pour provoquer la destruction des follicules et une grande diminution des niveaux d'ostrogènes dans le plasma, a empêché les effets lutéolytiques de la prostaglandine exogène. Des doses égales de $\mathrm{PGF}_{2} \alpha$ ont provoqué une lutéolyse complète et un retour de l'œestrus chez les Brebis témoins et chez les Brebis irradiées qui reçurent du benzoate d'œestradiol en plus de $\mathrm{PGF}_{2 \alpha}$.

Des déterminations des concentrations d'une protéine à haute affinité de liaison (saturable et spécifique) pour les œstrogènes dans des échantillons de corps jaunes bovins recueillis pendant le cycle cestral montrent que les concentrations sont basses ou non mesurables jusqu'au jour 5 , augmentent au jour Io, diminuent rapidement aux jours $r 7$ à $x 8$, tandis que les niveaux de progestérone baissent et augmentent brutalement jusqu'au jour 20. La prostaglandine exogène n'est pas capable de provoquer la régression du corps jaunc chez la Vache quand elle est administrée avant le jour 5 .

Les résultats mentionnés ci-dessus, pris dans leur ensemble, suggèrent que les œstrogènes sont peut-être l'un des agents responsables de la régression naturelle ou précipitée par $\mathrm{PGF}_{\mathbf{2} \alpha \text {, }}$ du corps jaune

\section{REFERENCES}

Baikd D. T., Collett R. A., Frasler J.S., Kelly R. W., Land R. B., Whelefe A. G., 1973. Progesterone secretion from the ovary in the ewe following infusion of uterine venous plasma. J. Reprod. Fert., 35, 13-22.

Brunner M. A., Doneldson L. F., Haxsel W., I969. Exogenous hormones and huteal function in hysterectomized and intact heifers. J. Dairy Sci., 52, 1849-1854.

ienternkamp S. E., Hansel W, i973. Concurrent changes in bovine plasma hormone levels prior to and during the first post-partum estrous cycle. J. Animal Sci., 37, 1362-1370.

Godisg J. R., 1974. The demonstration that $\mathrm{PGF}_{2 x}$ is the uterine luteolysin in the ewe. J. Reprod. Fert., 38, 261-271.

Hafs H. D., Lours T. M., Noden P. A., Oxender W. D., I974. Control of the estrous crele with prostaglandin $F_{2 x}$ in cattle and horses. J. Animal Sci., 38, Suppl. I, 10-22.

Hansel W., r97I. Survival and gonadotrophin responsiveness of luteal cells in vitro. Third Karolinska symposium on Research Methods in Reproductive Endocrinology: In vitro Methods in Reproductive Cell Biology., 295-3I8.

Hansel W., Concannon P. W., Lukaszewska J. H., I973. Corpora lutea of the large domestic animals. Biol. Reprod, 8, 222-245.

Hansei, W., Schechter R. J., I972. Biotechnical procedures for control of the estrous cycles of domestic animals. Proc. VIIth Int. Congr. Animal Reprod. and Artificial Insemin., vol I, 75-96. JIunich.

Iixon J. F., Gengenbach D. R., Hansel W., ig74. Failure of prostaglandin $F_{2} \alpha$ to cause luteal regrssion in ewes after destruction of follicles by x-irradiation. Proc. Seventh Annual Meting, Society for Study of Reproduction, Ottarea, p. Io (abst.).

HixON J. E., HANSEL. W., I974. Evidence for preferential transfer of prostaglandin $F_{2 x}$ to the ovarian artery following intrauterine administration in cattle. Biol. Reprod., 11, 543-552.

Hixon J. E., Nadaraja R., Schechter R. J., Hansel W., i973. Prostaglandin Fax induced stimulation of estrone and estradiol-r $7 \beta$ secretion in cattle. Prostaglandins, 4, 679.687.

Hobson W. C., HANSEl W., 1972. Plasma LH levels after ovariectomy, corpus luteum removal and estradiol administration in cattle. Endocrinology, 91, I85-190.

Hoffman L. H., 1974. Luteal regression induced by arachidonic acid in the pseudopregnant rabbit. $J$. Reprod. Fert., 36, 4 OI-404.

Kimball F. A., Hansel W., I974. Jistrogen rytosol binding protein in bovine endometrium and corpus luteum. Biol. Reprod., 11, 566-577. 
Roche J. 1., Karsch E. J., loster D. L., Dziuk P. J., I974. Serum LF in ewes following sequential removal of ovarian follicles, corpora lutea and stroma. J. Reprod. Fertil., 40, 215-2I8.

Rowsox L. E. A., TERvit R., BRAND A., I972. Synchronization of oestrus in cattle by means of prostaglandin $\mathrm{F}_{2 \alpha}$. Proc. IIIth. Int. Congr. Animal Reprod. and Artificial Insemin., Vol. II, p. 865, Munich.

Savard K., I973. The biochemistry of the corpus luteum. Biol. Reprod., 8, I83-202.

Scott T. W., Hansel W., Donaldson L. E., 1968. Metabolism of phospholipids and characterization of fatty acids in bovine corpus luteum. Biochem. J., 108, 317-323.

Shemesh M., HANSEL W., I974. Measurement of bovine plasma testosterone by radioimmunoassay (RIA) and by a rapid competetive protein binding (CPB) assay. J. Animal Sci., 39, 720-724.

Shemesh II., Hansel W., x975a. Arachidonic acid and bovine corpus luteum function. Proc. Soc. Exp. Biol. Med., 148, 243-246.

Shemesh I., HANsel W., I975 b. Levels of prostaglandin $\mathrm{F}$ in bovine endometrium, uterine venous, ovarian arterial and jugular plasma during the estrous cycle. Proc. Soc. Exp. Biol. Med., 148, I23I 26.

Shemesh M., Hixox J. I., Hansel W., 1974. Isolation and identification of endometrial Juteolysin. J. Animal Sci., 39, 337 (Abst.).

Stormshak F., Kelley H. E., HAwk H. IV., 1969. Suppression of ovine luteal function by I7 $\beta-$ estradiol. J. Animal Sci., 29, 476-478.

Thorburs G. I), Cox R. I., Currie W. R., Restall B. J., Schneider W., I972. I'rostaglandin I: concentration in the utero-ovarian venous plasma of the ewe duting the estrous cycle. J. Endocrinol, 53, 325-326. 